\title{
François Delalande: \\ a pedagogia do despertar musical
}

\section{François Delalande:}

\author{
the pedagogy of musical awakening
}

\section{Alessandra Cintra Alarcon' \\ Teca Alencar de Brito ${ }^{2}$}

1 Graduada em Letras (Portuguê/Francês) pela UNESP (2007), possui pela Université Paris VIII (Vincennes/ Saint-Denis) graduação em Musicologia com especialização em Ciências da Educação (2016). Como docente e tradutora, desenvolve trabalhos não apenas relacionados à língua francesa, mas também à educação musical, sendo professora assistente de musicalização na TECA Oficina de Música. Tem formação pela EMESP (Escola de Música do Estado de São Paulo) em Canto Popular. Foi responsável pela tradução de $A$ música é um jogo de criança, primeiro livro de François Delalande vertido para a língua portuguesa. Email: alemusique@gmail.com 2 Doutora e Mestre em Comunicação e Semiótica pela PUC-SP, Bacharel em Piano e Licenciada em Música, responsável pela Teca Oficina de Música, núcleo de formação musical fundado há 35 anos, em São Paulo - SP. Autora de livros na área, produziu também nove CDs documentando o trabalho desenvolvido na Teca Oficina de Música. Professora e pesquisadora no CMU-ECA-USP, no curso de Licenciatura em Música e Pós-Graduação em Musicologia, na linha de pesquisa Música e Educação: processos de criação, ensino e aprendizagem. É autora de diversos livros sobre Educação Musical, dentre eles Música na educação infantil: propostas para a formação integral da criança, todos publicados pela Editora Peirópolis. 


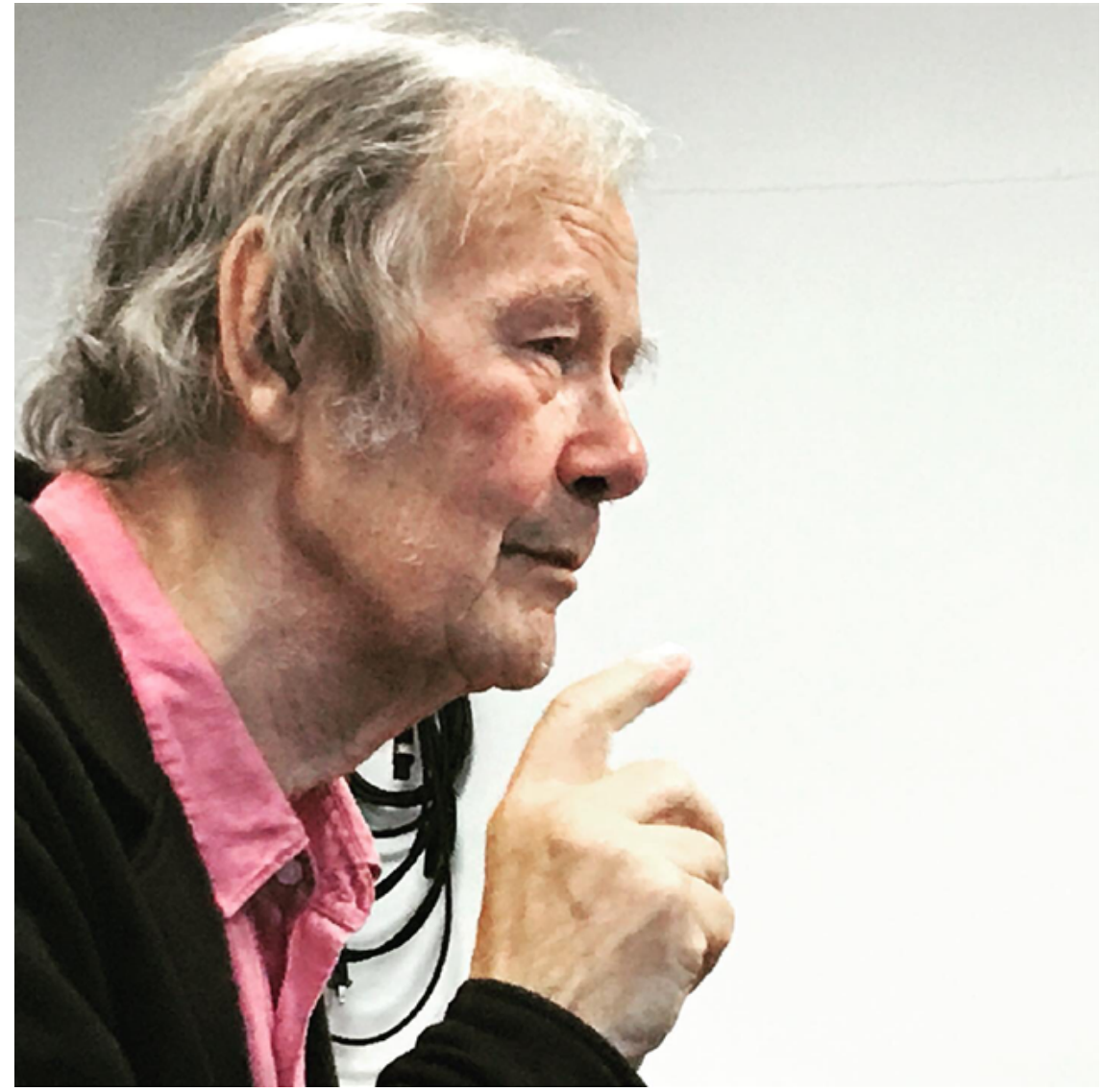

Legenda: François Delalande - crédito: Pedro Paulo K. Bodesan dos Santos.

François Delalande é considerado um dos principais nomes atuais da pedagogia musical, cujas propostas priorizam, sobretudo, as práticas criativas. Foi um dos mais importantes organizadores do Groupe de Recherches Musicales (GRM), centro ligado ao Instituto Nacional de Audiovisual, em Paris, onde atuou entre 1970 e 2006. Seu trabalho científico apresenta dois eixos principais: o primeiro compreende a análise de músicas eletroacústicas, de uma música sem notas ou para além das notas, isto é, que parte dos sons e das condutas humanas de escuta e de produção musical; o segundo investiga o nascimento e o desenvolvimento dessas condutas no curso da infância, com objetivos pedagógicos.

Ao longo de quase cinco décadas de intensas pesquisas nas áreas da análise e da pedagogia musicais, seus principais títulos são: L〉enfant du Sonore au Musical, (1982); La musique est un jeu d>enfant (1984); Le condotte musicali - textos traduzidos em italiano e apresentados por Luca Marconi e Giovanna Guardabasso (1993); «Il faut être constamment un immigré », entretiens avec Xenakis, (1997); Le « son » des musiques, entre technologie et esthétique, (2001); La 
nascita della musica: explorazioni sonore nella prima infanzia (2009); Analyser la musique, pourquoi, comment? (2013); Naissance de la musique, les explorations sonores de la première enfance (2015).

Em 2019, foi lançada a versão portuguesa de sua obra mais difundida: La musique est un jeu d'enfant. Segue abaixo a entrevista ${ }^{3}$ gentilmente concedida por Delalande durante sua passagem pelo Brasil para o lançamento do livro $A$ música é um jogo de criança, igualmente para a realização de Conferências na Universidade Federal do Mato Grosso do Sul, na Universidade de Brasília (UnB), no Conservatório Brasileiro de Música, no Rio de Janeiro, na Universidade de São Paulo (USP) e na Teca Oficina de Música, em São Paulo.

Trata-se de um registro captado oralmente, o qual só depois foi transposto para a linguagem escrita. Revelador de sua visão epistemológica, a entrevista traz informações e reflexões relevantes sobre os inúmeros trabalhos realizados no seio do GRM e de suas mais recentes pesquisas na área da Pedagogia Musical. As linhas, a seguir, prestam-se, simultaneamente, não apenas como um convite para aqueles que ainda não fizeram a leitura de $A$ música é um jogo de criança, mas também como uma fecunda fonte de aprofundamento das ideias do teórico francês.

I. Conte-nos um pouco sobre sua formação musical.

No início, minha formação era em Matemática e Física. Eu sou engenheiro, logo, fiz meus estudos completos em Engenharia. Um dia vi um programa do Pierre Schaeffer na televisão. Pierre Schaeffer é o inventor da música concreta. Nesse programa, ele disse por alto: "Se você for engenheiro e se você for músico venha integrar o GRM" (Grupo de Pesquisas Musicais).

Na verdade, não era tão simples assim. Normalmente era necessário fazer um estágio de um ou dois anos e, só depois disso, seria eventualmente possível desenvolver algo lá. Porém, eu cortei um pouco o caminho. Não sei se devo entrar nesses detalhes, mas isso foi importante para mim. Eu era engenheiro e, paralela-

3 Entrevista realizada no dia 13 de junho de 2019, na Teca Oficina de Música. 
mente, tocava órgão, estudava harmonia, mas não muito. Por exemplo, eu nunca estudei no Conservatório Superior de Paris. Eu queria entrar lá, mas naquela época a pessoa que cuidava do processo seletivo me disse que para compor era melhor ser engenheiro do que ter estudado fuga, harmonia e contraponto. Até mesmo meu professor de harmonia me aconselhou a entrar no GRM, dizendo que ele também tinha esse desejo, mas que era muito complicado. Assim, eu fiz um estágio de observação durante três meses lá.

Eu escutei tudo, li todos os livros e François Bayle, diretor do GRM naquela altura, disse o seguinte: “ Como você realizou esse estágio, você poderia redigir um pequeno relatório sobre o que você fez aqui." Eu sabia que esse trabalho seria muito importante para mim e acredito que ele tenha ficado bom. François Bayle o entregou para Pierre Schaeffer. Assim, um dia, ao cruzar Schaeffer numa escadaria, ele me disse: "Eu li o seu relatório, diga a Bayle que o seu lugar é no GRM." Ora, isso foi incrível! A escrita de um pequeno relatório como o que eu havia feito mudou completamente minha vida!

2. Você poderia nos falar um pouco mais sobre o que é o GRM?

O GRM é o Grupo de Pesquisas Musicais do INA (Instituto Nacional de Audiovisual Francês), fundado por Pierre Schaeffer. Ele foi a primeira pessoa que começou a fazer música com máquinas e não com partituras e intérpretes. Em estúdio, compunha músicas combinando sons gravados em discos. Gravava os discos, misturava os sons e fazia montagens. Foi assim que ele fez Cinq études de bruit, em 1948.

Depois disso, surgiu o Grupo de Pesquisa de Música Concreta, o qual, em 1958, deu origem ao GRM, este último mais orientado para a pesquisa do que para a composição. Assim, deu-se origem à música eletroacústica, pois a partir de 1950, paralelamente, surge em Colônia, na Alemanha, sobretudo através da figura de Stockhausen, a música eletrônica. Como a música eletrônica e a música concreta eram feitas sem partituras e sem intérpretes, inventou-se uma palavra que abarcava um pouco tudo isso: a música eletroacústica. Dessa forma, o GRM é o ponto de partida da música eletroacústica. 


\section{Quais linhas de pesquisa você desenvolveu no GRM?}

Durante dois anos eu dei cursos de composição de música eletroacústica, o que é bem estranho, pois, na verdade, eu nunca tinha feito isso. Mas isso era o GRM. Eu sabia muitas coisas sobre a música eletroacústica. Sabia fazer montagens, mixagens e tinha feito muitas análises musicais, além disso, eu escutava muitas coisas. Então, eu orientava os compositores. Fiz isso durante dois anos com Guy Reibel. Depois, tornei-me chefe de trabalhos de pesquisas e isso me permitiu coordenar inúmeras pesquisas nessa área. Rapidamente, eu criei uma oficina de análise de música eletroacústica, ou seja, dessa música que não estava escrita em partituras.

Posso dizer que esse é o principal eixo do meu trabalho: a escuta musical, pois como esse tipo de música não está escrito, em geral, o primeiro passo é escutá-la para poder ver como ela se organiza. Consequentemente, o trabalho começa pela escuta, em seguida, emergem problemas de análise que são mais ou menos os mesmos das músicas étnicas, as quais também não são escritas. Portanto, é uma espécie de teoria da análise e, por fim, posso dizer que faço muitas teorias da análise, sendo essa a minha principal linha de pesquisa.

\section{E como surge sua relação com a Pedagogia Musical?}

Paralelamente a esses estudos, eu me dei conta de que a maneira dos compositores concretos trabalharem - experimentando, modificando e escutando empiricamente - era muito próxima do que as crianças faziam, uma vez que elas produzem sons dessa maneira: experimentando, isto é, quando gostam de um som, elas o repetem realizando variações.

Em vista disso, eu abri uma oficina de observação e de experimentação nas escolas maternais, ou seja, com crianças entre três e seis anos. Havia cinco ou seis pessoas que trabalhavam comigo e que realizavam os experimentos nas aulas. Nós publicamos primeiramente um pequeno livro baseado nessas observações intitulado Pédagogie Musical d'Éveil, para o qual eu escrevi o artigo "Trois idées clés pour une 
pédagogie musicale d'éveil”" . Foi o meu primeiro texto sobre esse assunto. Aliás, eu o reli não faz muito tempo, para ministrar cursos para a formação de professores em Paris e, ao que me parece, as coisas não mudaram. Enfim, penso que o conteúdo que está nesse livro é muito verdadeiro.

As três ideias-chave são: em primeiro lugar, a criança faz a música dos sons por si própria; em segundo, a música não é somente dó, ré, mi, fá, sol e tudo que sabemos do sistema tonal; em terceiro, o objetivo inicial não é formar crianças que saibam música, mas formar músicos. E ser músico não é saber música, pois nós podemos desenvolver uma série de gostos e de aptidões antes de começar a ensinar o solfejo e as técnicas instrumentais. A princípio, devemos despertar as condutas musicais que existem nas crianças, favorecendo suas atividades espontâneas de escuta e de produção de sons. Em suma, são essas ideias que eu desenvolvi bastante.

5. Você dirigiu diversas pesquisas em creches e escolas, não apenas na França, mas também na Itália. Como é feita, em linhas gerais, a formação dos professores que integram suas equipes?

No início, quando eu fazia experimentações na educação infantil, havia muitas pessoas interessadas em trabalhar comigo. Tratava-se de músicos e estagiários do GRM que faziam o estágio de dois anos de duração - o qual eu não precisei fazer -, e que tinham interesse pelas problemáticas da educação. Eu me lembro, por exemplo, de Claire Renard que tinha filhos pequenos e que também suspeitava de que existisse uma nova direção para a educação musical. Consequentemente, nós trabalhamos juntos e esse primeiro trabalho, no maternal, durou até a escrita do livro que mencionei anteriormente, Pédagogie Musicale d'Éveil, publicado em 1976.

Depois disso, ainda no eixo da educação, eu comecei a me perguntar por que iniciar as pesquisas somente aos três anos? Talvez devêssemos começar antes, por

4 Três ideias-chave para uma pedagogia musical do despertar. 
razões mais teóricas. Porque se desenvolvemos as condutas, as aptidões musicais, precisamos, então, saber de onde isso vem e como isso começa. Desse modo, passei a me interessar mais pelas crianças menores, de creche ${ }^{5}$. Nessa época, trabalhei com duas psicólogas, Bernadette Céleste e Élisabeth Dumaurier, e nós fizemos um segundo livro intitulado L'enfant du sonore au musical. Com Bernadette, observei as crianças de creche através de meios ainda bastante rudimentares. Nós construíamos corpos sonoros, colocávamos as crianças diante deles e depois observávamos o que elas faziam. Isso foi o que eu sempre fiz na creche: colocar as crianças diante de um corpo sonoro e observar como ocorre essa exploração. Eu fiz isso quatro vezes na minha carreira. Essa foi apenas a primeira delas.

Posteriormente, em Paris, retomei esse tipo de pesquisa com outro psicólogo. Como eu dirigia pesquisas, podia contratar pessoas para trabalhar comigo. Nós fizemos observações principalmente com um pandeiro. Colocávamos crianças pequenas, no berço, em frente ao instrumento. A partir do primeiro contato, o instrumento emitia um som. Dessa forma, buscávamos analisar o que as crianças fariam em seguida, como elas raspavam, arranhavam, batiam. Percebemos, por exemplo, que elas não batiam muito como imaginávamos. Elas mais raspavam e arranhavam. Fizemos isso com mais de cem crianças e filmamos muitas situações. Essa foi minha segunda série de observações.

Mais tarde, comecei a fazer contatos na Itália e a terceira série de observações se passou em Florença. Pediram-me para fazer uma formação musical de educadores de creche. Julguei que isso não seria uma boa ideia. Então, dei uma formação para a observação e pedi que comprassem câmeras de vídeo. Ensinei as professoras a observar e a anotar sistematicamente o que as crianças faziam, mesmo quando elas estavam sentadas na mesa, que tipo de som elas realizavam, quais interações estabeleciam, enfim, tudo que era produção sonora.

5 Na França, as creches atendem crianças entre a faixa etária de dois meses a três anos. 


\section{Então, não era uma formação musical para educadores de creche?}

Não. Eu tentava convencer as pessoas que me pediam para fazer isso, que eu não tinha nenhum interesse em realizar esse tipo de formação. O que é necessário fazer com as crianças de creche é ser capaz de observar o que elas fazem espontaneamente e provocar situações. Temos o exemplo de um garoto de dezesseis meses que foi colocado em frente a dois pratos. Ele fez uma série de explorações guiadas pela própria escuta, adotando o que Piaget chama de uma "conduta experimental". Isso foi gravado pelas educadoras. Assim, elas filmavam o que elas achavam interessante. Nós disponibilizamos alguns materiais e dávamos instruções de observação dizendo: "É preciso fazer isso e aquilo, agora você vai colocar a criança nessa situação, etc." Elas não eram musicistas. O trabalho delas era cuidar das crianças.

Depois, retomei esse trabalho em Lecco, no norte da Itália, no Centro de Estudos Musicais e Sociais M. di Benedetto (CSMDB) ${ }^{6}$ e os resultados dessa experiência foram publicados no livro Naissance de la musique7. O diretor desse centro propôs-me realizarmos uma pesquisa mais aprofundada sobre as creches. Nós, então, constituímos uma equipe importante, com aproximadamente uma dezena de pesquisadores: um comitê científico, pessoas que iam filmar nas creches anotando a que horas cada atividade tinha sido feita. Uma equipe com cerca de quinze pessoas em condições de trabalho absolutamente ideais. Eu nunca fiz uma pesquisa com condições tão perfeitas: equipe, material, dinheiro e possibilidade de comprar os instrumentos necessários. Foi tudo perfeito, principalmente pela presença de Silvia Cornara, a qual se ocupava das filmagens. Ela era psicóloga e foi extremamente precisa. Por isso, durante três anos, nós filmamos as crianças em diferentes situações.

Em seguida, tive todo um trabalho de análise, de estatística. Começamos a

\footnotetext{
6 https://www.musicheria.net/

7 Primeiramente, publicado em italiano: La nascita della musica, em 2009, cuja versão francesa foi lançada em 2015, com o título de La naissance de la musique.
} 
pesquisa em 2002 e lançamos o livro em 2009. Trabalhamos durante sete anos com todo esse material. Eu preciso dizer, aliás, que nós filmamos muitas coisas. Nós temos muitos vídeos que foram analisados, obviamente, sob certos pontos de vista. Mas, evidentemente, é possível pegar o mesmo corpus de vídeos que está muito bem documentado - com a idade das crianças, data, hora, etc. - e fazer outras pesquisas sobre eles.

Como sou consciente da importância desse material, pedi ao centro de pesquisas em questão para colocar todo o material à disposição de pessoas que queiram trabalhar com ele. Assim, tudo está disponível: os vídeos, as fichas, as transcrições. Eles vendem isso pelo preço de um disco duro externo de computador. Tudo está lá. Um pesquisador, que tenha vontade de fazer sua tese com esse material, pode dispor de tudo isso, realizando um trabalho diferente, encontrando outras coisas. Eu fiz isso, inspirado em Jean Claude Risset que, no domínio da informática, realizou trabalhos sobre a síntese de sons em computadores, nos Estados Unidos, tendo posteriormente publicado todos seus trabalhos. Ele se refere a esses documentos como um catálogo de sons, como os sons foram programados, com quais ferramentas. Assim, quando a informática musical começou a se desenvolver na França, todo mundo utilizou essa documentação.

7. Aproveitando que estamos falando das pesquisas que resultaram na publicação do livro Naissance de la musique, nessa obra existem dados demonstrando que I/3 das crianças analisadas não tocavam os instrumentos na presença do professor. Eu gostaria de saber como esses dados podem orientar os educadores, levando em consideração que, numa situação de aula, eles não podem se ausentar da sala, e também que, em geral, as turmas são numerosas.

No último capítulo desse livro, há justamente uma série de reflexões sobre o problema do barulho, do ambiente, basicamente. Por exemplo, é bom deixar uma cítara permanentemente no quarto da criança? Eu não sei responder essa questão. O que sei é que dar a cítara à criança, dois meses após algumas experimentações, por exemplo, faz com que ela se interesse novamente pelo instrumento, porque o 
que motiva a exploração é quando descobrimos algo. Por isso, não me parece muito interessante fazer as crianças explorarem todos os dias os mesmos objetos. É importante que elas se esqueçam disso um pouco para que, depois de algum tempo, elas os redescubram.

\section{Então, os professores podem usar essa estratégia para estimular as des- cobertas e experimentações sonoras das crianças?}

Todo o problema de dispositivos é verdadeiramente o trabalho dos professores. Tudo que eu posso dizer, simplesmente, após essas observações, é que uma criança pode explorar sozinha. E isso eu já sabia, pois já havia observado anteriormente, em outras pesquisas. Mas, o que eu não sabia, até então, é que 1/3 das crianças só exploravam os corpos sonoros quando estavam sozinhas. Assim, que conclusão pode ser tirada? Eu diria que seria muito interessante ter um local, um pequeno espaço no qual a criança possa ir sozinha, mesmo na sala de aula. Por exemplo, um armário colocado de forma perpendicular à parede, ou seja, um lugar em que o professor seja capaz de vigiá-la, mas que dê a ela a sensação de estar sozinha, guardando certa distância dos colegas, pois as crianças conseguem se concentrar mesmo quando há barulho por perto. Isso é algo que me surpreende nos vídeos. Às vezes, havia muito barulho nas salas, mas mesmo assim sempre tinha uma criança que estava concentrada fazendo sons com a cítara. Porém, havia uma creche mais silenciosa, com uma educadora que falava também mais baixo, onde eu acho que as explorações foram muito melhores. Então, é interessante que o ambiente seja o mais silencioso possível e que exista um lugar onde a criança possa ir explorar sozinha. E isso é um problema de arquitetura.

Nesse livro, eu faço uma observação para os arquitetos, pois, quando construímos uma escola, é preciso pensar em tudo isso. Se fizermos classes barulhentas nas quais as crianças não possam se isolar, nós, infelizmente, perdemos algo. Evidentemente, é necessário poder vigiar as crianças, mas basta separar com um vidro ou com placas acústicas quando construímos o lugar e adaptá-lo não é algo tão complicado de ser feito. Eu trabalhei muito tempo com uma educadora chamada Monique 
Frapat e, na escola onde ela trabalhava, havia um espaço que ficou conhecido como o espaço da música, onde as crianças podiam trabalhar sozinhas.

9. Monique Frapat parece ter tido um papel importante em suas pesquisas. No livro $A$ música é um jogo de criança você observa algumas atividades coletivas que ela conduziu. Ela não tinha nenhuma formação musical?

Nenhuma. É uma experiência particularmente interessante e muito próxima da situação de muitos professores da educação infantil: pessoas que não possuem formação musical, mas que têm certo talento pedagógico, um gosto por observar as crianças e que são capazes de deixá-las explorar por si mesmas.

Sempre falo sobre uma atividade interessante que Monique Frapat desenvolveu com uma turma de alunos de cinco anos. Ela os levou para visitar uma lavanderia que ficava próxima à escola e, no caminho de volta, observou que algumas crianças estavam imitando os sons das máquinas de lavar. Depois, elas retomaram esses sons num lugar onde podiam encenar as máquinas. E, posteriormente, isso se tornou um espetáculo. Monique Frapat teve uma experiência bastante longa de invenção musical na educação infantil e seu filho que gostava bastante de filmar - inclusive, hoje, é cineasta - vinha com frequência registrar as crianças. Dessa forma, nós temos um enorme corpus de vídeos. Nós fizemos uma entrevista com a Monique Frapat para que ela contasse sobre essas experiências e tudo isso está disponível na internet.

Io. La musique est un jeu d'enfant é o seu livro mais difundido e traduzido. Após trinta e cinco e anos da primeira edição, acaba de ser lançada uma versão em português. Em sua opinião, por que essa obra é ainda tão atual e continua a impactar tanto os leitores?

Talvez porque as crianças continuem sendo as mesmas, mesmo depois de trinta e cinco anos ou mesmo depois de mil! Elas evoluem mais ou menos da mesma maneira. Com a música não é a mesma coisa. Depois da segunda metade do século 
XX, podemos pensar a música de uma maneira mais próxima das crianças. A música começa a se assemelhar com o que as crianças fazem. Isso não foi sempre assim.

Quando fazíamos a música unicamente tonal, por exemplo, ou unicamente com notas, as crianças estavam distantes disso. Mas agora que a música utiliza muito o som como elemento de construção - a qualidade do som, aquilo que chamamos de singularidades sonoras, ou seja, algo que no plano sonoro é original sendo então desenvolvido - isso está muito próximo daquilo que as crianças fazem. E de fato, depois da metade do século XX, essas ideias estavam disponíveis. Mas, quando eu comecei a constatar isso, ninguém ainda havia observado que a música que as crianças faziam era muito próxima da música feita pelos compositores da época.

\section{I. E você fez isso quando publicou o livro $A$ música é um jogo de criança, em 1984?}

Não, um pouco antes, quando fiz o livro mencionado anteriormente, Pédagogie Musicale d'Éveil, publicado em 1976. No entanto, ele já tinha sido publicado em 1974, num programa de um concerto. Ao invés de dar somente o programa com as informações sobre a obra, colocavam também um artigo para fazer o público refletir. Eu escrevi o artigo “Trois idées clés pour une pédagogie musicale d'éveil”, em 1973. Eu me lembro disso muito bem, pois me perguntava como intitular essa pedagogia musical que tinha como objetivo despertar o gosto pelo fazer musical, despertar aptidões, mas não ensinar música. Inicialmente, o objetivo não era ensinar música, mas despertar algo nas crianças. E o conceito de "éveil" - despertar - existia muito na França. Eu mesmo tinha sido professor de química e tinha feito, com estudantes de doze anos, uma espécie de éveil para a química. Eu pedia-lhes para fazer pequenas experiências, sem explicar as fórmulas e as moléculas, buscando motivar neles o prazer de fazer tais experimentos.

No caso da música, era a mesma coisa, ou seja, despertar o prazer pelo fazer musical. Sendo assim, pareceu-me pertinente falar de pedagogia musical do despertar. Isso aconteceu em 1973. Eram ideias completamente novas. Depois disso, eu 
comecei a fazer programas radiofônicos na rádio France Culture. Eu fazia todas as semanas um programa de meia hora que se chamava Éveil à la Musique.

\section{Foi essa a gênese para o livro $A$ música é um jogo de criança?}

Sim. Havia um programa semanal, cujas emissões eram realizadas juntamente com Guy Reibel. Nós encontrávamos aulas que nos pareciam bem inovadoras para gravarmos as crianças, para conversarmos com os professores, enfim, para difundirmos isso tudo na rádio. No entanto, uma vez por mês, Jack Vidal e eu fazíamos uma entrevista mais geral e teórica sobre o gesto, a escuta e as palavras para descrever os sons. Em suma, são essas questões gerais que serviram de ponto de partida para o livro.

13. E voltando a ideia de que o livro continua atual...

Eu tive que relê-lo recentemente para reeditá-lo e ver se ele continuava atual. Somente retirei da discografia certo número de títulos que não existem mais. No entanto, eu não mudei nada das ideias do texto. E me dizia: "Esse livro é muito bom!" (risos). Fiquei muito contente em relê-lo. Com frequência, muitas pessoas me dizem que esse livro mudou a maneira delas de ensinar, de conceberem a música. Isso me toca e ao mesmo tempo me surpreende, porque eu tenho a impressão de que as ideias que estão nele são bastante simples se refletirmos um pouco. $\mathrm{Na}$ verdade, acredito que ele toca muito as pessoas que estavam prontas para, dentro da própria trajetória, abordarem a música de um modo diferente do que pelo solfejo, pelas técnicas, etc. Pessoas que viam bem que os métodos ativos Orff, Martenot, entre outros, são métodos que conduzem à música tonal e que, com efeito, não estávamos mais nesse momento. Havia muitas pessoas que já sentiam isso e bastava para elas encontrar uma espécie de formulação explícita do que elas sentiam implicitamente, algo que é muito importante para mim. 


\section{Qual deve ser o papel do professor que coloca em prática a pedagogia baseada na criação?}

Primeiramente, é importante ver o que é preciso evitar. Em geral, quando as crianças começam a brincar, a produzir sons, o comportamento dos pais e dos adultos é pedir a elas para que fiquem quietas: “- Você está me incomodando com esse barulho!" Isso é típico. Vejo isso frequentemente com meus amigos, como por exemplo, quando uma criança começa a empurrar uma cadeira contra o chão, o que é, no entanto, extremamente interessante como instrumento (ele imita com a boca os sons da cadeira sendo arrastada). Em suma, o comportamento habitual é dizer: “Pare já com isso, nós estamos conversando! Comendo! Isso incomoda!” E, de fato, muitas vezes os barulhos incomodam. Então, a primeira coisa para um professor é aceitar esse incômodo e tentar vê-lo não mais como um incômodo, mas como algo a ser observado.

Dessa forma, quando uma criança brinca de produzir sons e fazer variações, o professor deve ser capaz de perceber isso, o que já é muito importante. Em seguida, numa educação pautada na criação, é importante perceber que é a criança que descobre e não o educador que diz faça isso ou faça aquilo. É necessário deixá-la escolher, descobrir, e assim, favorecer o seu comportamento, ou seja, ajudá-la a descobrir, mas não descobrir para ela.

Portanto, constatamos e retomamos novamente a importância da disposição dos objetos. Podemos tomar como exemplo a amplificação através da utilização de um microfone. Ao explorar sons diante de um microfone, mesmo que sejam sons com os quais já estamos acostumados, o fato de estar amplificado o torna novo, traz uma sensação de novidade e isso estimula a vontade de explorar. Por exemplo, um copo de plástico que amassamos ou rasgamos perto de um microfone produz um som fantástico! Podemos chamar esse sistema de amplificação de dispositivo, pois o contexto sempre favorece uma conduta. E esse é o papel dos educadores, inventar bons dispositivos, uma boa disposição, boas circunstâncias para que algo se produza, sem ter que dizer à criança: “- Faça isso”! 
Os educadores verdadeiramente talentosos vão encontrar um modo de organização que estimula as crianças a fazerem aquilo que esperam ou algo próximo de suas pretensões. Assim, o educador não vai dizer que gostaria que a criança fizesse um determinado som "chiii”, mas, por exemplo, gostaria que ela explorasse as possibilidades de um determinado corpo sonoro. Por conseguinte, ele vai criar as condições para que a criança assim o faça. Esse é o papel dos educadores: encontrar as circunstâncias e os dispositivos para que as crianças inventem. Ele não vai impor, vai guiá-las.

\section{No livro A música é um jogo de criança, você fala sobre os estágios sen- sório motor, simbólico e jogo de regras. Qual é a relação entre esses estágios: sucessão, coexistência, predominância?}

Eu não acredito que seja uma relação de sucessão. Essa terminologia foi elaborada por Piaget e mesmo para ele não é uma sucessão. Mas, é evidente que Piaget deu idades muito aproximativas e que foi somente depois que começamos a compreender melhor como os períodos se encadeavam. O desenvolvimento de uma criança no primeiro ano de vida é fortemente impregnado pelo sensório-motor: os gestos, as sensações. Isso começa claramente pelo sensório-motor.

Depois, há o jogo simbólico. De uma maneira geral, o simbolismo se desenvolve na vida da criança quando algo pode evocar outra coisa. Quando há uma relação de referência. Mas em que idade isso aparece? Eu sei que no segundo ano de vida da criança o simbólico já está presente. Mas talvez já no primeiro ano ou mesmo antes. Porém, nós ainda não podemos saber. Nós não temos muitos meios e é muito difícil observar o simbolismo sem ser através de comportamentos já mais desenvolvidos. Evidentemente, quando as crianças começam a falar, o simbólico começa a aparecer, pois elas evocam pelas palavras algo que não é o som.

Quando minha filha tinha dezesseis meses, ela estava brincando com a janela que fazia um rangido e ao ouvir o som, ela disse "bebê" e começou a rir. Ela não sabia falar, mas ela fez a associação do ranger da janela com um bebê que chora. Assim, eu 
sei bem que o simbolismo que se torna muito importante com quatro anos, já está presente com dezesseis meses e, talvez, até mesmo muito antes.

Já o sensório-motor está sempre presente. Mesmo os jogos de exercícios tornam-se jogos simbólicos e podem se combinar com jogos de regras. Por exemplo, o jogo de amarelinha é tipicamente de origem sensório-motora, pois é necessário saltar. Mas, esse jogo apresenta também uma dimensão simbólica - a terra, o céu e há também regras porque não se pode, por exemplo, pisar nas linhas. Logo, ele agrupa todas as três dimensões: sensório-motora, simbólica e jogo de regras. E a música é o sensório-motor, simbólico, com regras. Porém, há predominâncias dessas dimensões de acordo com o tipo de música, de cultura.

\section{I6. Em uma de suas conferências no Brasil, você falou sobre a passagem da} criação para a passagem do aprendizado na música. Como se dá esse processo?

Esse problema sempre aparece quando colocamos em prática uma pedagogia de criação. O que se passa após uma criança entrar no Conservatório, por exemplo. Ela vai aprender a tocar flauta. O que acontece? É um problema bastante clássico que não é próprio à música. Eu vou responder apenas para a música. Mas nós temos sempre o mesmo problema, na França, com crianças da educação infantil entre três e cinco anos. Não sei se no Brasil é igual. Em geral, na educação infantil, as crianças ficam bastante livres: elas pintam, brincam de massinha, etc. Quando vão para o Ensino Fundamental, com seis anos, elas são colocadas em fila, atrás de carteiras com uma professora diante delas. É uma mudança radical de pedagogia. Então, o problema não é próprio à música. Efetivamente, é questão de encontrar uma transição que não seja tão brutal.

$\mathrm{Na}$ escola de educação infantil, onde Monique Frapat trabalhava, todos os professores praticavam uma pedagogia de invenção na música. Assim, quando as crianças iam para o Ensino Fundamental elas se sentiam perdidas. Indagavam-nos sobre a continuidade das aulas de música. Enfim, elas se sentiam bem descontentes. E nós fomos obrigados a abrir um curso de criação na escola, extracurricular, para 
que as crianças pudessem continuar a fazer criações musicais. Todas as gravações que eu mostro de crianças, entre cinco e seis anos, foram feitas nesse contexto de ateliês paralelos à escola para que as crianças pudessem continuar a fazer música e realizar uma passagem menos brutal da educação infantil para o ensino fundamental.

De fato, podemos ter o mesmo problema quando passamos de uma atividade de criação para uma atividade de aquisição de técnicas e do solfejo. E, na verdade, não é tão complicado. Basta fazer uma transição suave. Há professores de piano, por exemplo, que sabem disso e começam guiando os alunos a fazerem uma exploração do piano, a fazerem clusters e montarem pequenas melodias e, pouco a pouco, introduzem o solfejo. É uma pena começar a aprender o solfejo antes de tocar o piano. Se começamos tateando um pouco, podemos muito bem inventar pequenas melodias com notas que vão juntas, as quais se parecem, como dizia Mozart, introduzindo gradativamente as técnicas, dizendo ao aluno, por exemplo, se você colocar a mão assim, fica ainda melhor.

Mas é verdade que existe um problema. O que eu digo sempre é que há muitas competências que foram desenvolvidas nas atividades de criação que são transferíveis, ou seja, que serão reutilizadas quando tocarmos um instrumento. Tudo, aliás, começa pelo sensório-motor. É absolutamente fundamental ver que tocar um instrumento é uma relação sensório-motora com um instrumento. Devemos dominar o gesto e para conseguir isso é preciso utilizar todos os receptores sensoriais: a escuta, evidentemente, mas não só ela, o toque também. Quando tocamos um instrumento de sopro, há o desafio de saber como controlar a pressão do ar no abdômen. Enfim, há toda uma série de dimensões sensório-motoras que são indispensáveis na execução instrumental para obter um som bonito.

Podemos refazer todo esse trabalho quando temos sete ou oito anos, mas é uma pena porque poderíamos ter começado antes. Há períodos sensíveis como esse. Quando a criança está completamente imersa no sensório-motor é uma pena não explorar isso e começar a desenvolvê-lo apenas quando chegar ao Conservatório. O mesmo acontece com a expressão, ou seja, com o simbolismo.

Há um exemplo, em minhas pesquisas, de um grupo de crianças encenando 
corporal e musicalmente uma tempestade, representando ora o estado calmo do mar, através de sons suaves, ora a agitação das ondas, com gritos que pareciam expressar o medo da tempestade. Tudo são dimensões expressivas que podem ser reinvestidas na execução instrumental. Eu sei, por experiência, quando vejo instrumentistas muito bons, que isso acontece não porque eles sabem ler as partituras e tocá-las, mas porque eles têm um som fantástico, expressivo. Porque eles são suficientemente inventivos na maneira de interpretar. Não é fazer notas, não é a técnica: é a sonoridade, a expressão e a invenção, e é tudo isso que desenvolvemos na primeira infância.

Desse modo, o essencial, o mais difícil de adquirir na execução de um instrumento é justamente o que podemos fazer antes de pegar um instrumento em mãos. Evidentemente, podemos fazê-lo também quando tocamos um instrumento. Fazemos, em geral, ao mesmo tempo. Mas poderíamos ter começado antes.

I7. Gostaria de saber mais sobre o seu mais recente projeto de criação em computadores com crianças. Existe uma idade ideal para começar a desenvolver esse trabalho?

Nós fazemos há muito tempo composição assistida por computadores com crianças mais velhas. Começamos esse trabalho na França, com crianças entre doze e quinze anos, no final dos anos 1980 e publicamos dois pequenos livros. Nessa época, não existia ainda um sistema de som no computador. Havia um computador que comandava um sintetizador analógico, ligado por um sistema midi. Por que fazíamos isso? Basicamente, porque isso as interessava.

Atualmente as coisas evoluíram muito. Sabemos hoje que as crianças de dez anos podem compor com computadores, mas não faz muito tempo que descobrimos isso. Em 2011, eu recebi um convite de Emanuele Pappalardo ${ }^{8}$ para fazer uma série de programas sobre a criação musical, na rádio Vaticana, que recebeu o nome de La composizione è un gioco da bambini, paráfrase do livro A música é um jogo de criança.

8 Professor no Conservatório de Música Ottorino Respigui di Latina, na Itália. 
Posteriormente, Emanuele Pappalardo e eu montamos um projeto, no qual quinze alunos de uma classe do ensino fundamental I - crianças com dez anos - vinham uma vez por semana ao Conservatório onde Pappalardo dava aulas. Tínhamos um projetor, o material necessário.

\section{Computadores também?}

Não, os computadores eram trazidos pelas crianças. Computadores da família. Na verdade, nenhuma criança usava computador antes dessa experiência. É engraçado, pois elas conhecem os telefones celulares, os tablets. Mas elas só tinham o hábito de utilizar os tablets tácteis. Então, primeiro, Emanuele Pappalardo mostrou como utilizar os softwares. Depois, a cada semana, as crianças deviam fazer em casa uma pequena composição de aproximadamente um minuto. Elas utilizaram bases de sons pré-gravados que encontramos na internet, que disponibilizamos para elas e, eventualmente, alguns sons gravados nas aulas com objetos sonoros ou com o corpo - vozes, batidas de pés, etc. - tudo registrado com um gravador digital para poder passar, em seguida, para o computador.

Todas as semanas, elas traziam algo que haviam inventado e mostravam para outras crianças. Como resultado, a comunicação que se estabelece entre as crianças é muito interessante, fazendo com que, pouco a pouco, elas criem um hábito de análise. Nessas discussões, o professor complementa as impressões evocadas pelas crianças com alguns conceitos e termos mais técnicos. Dessa forma, há uma espécie de enriquecimento do vocabulário delas nessa partilha com os adultos. Eu, particularmente, acho essa situação muito interessante, pois a criança faz algo na casa dela, mostra para o colega e eles conversam sobre essa criação. Isso responsabiliza a criança. É a obra dela que está sendo exposta e todo mundo poderá fazer comentários sobre isso.

Realizamos dez sessões e, durante sete encontros, as quinze crianças fizeram uma obra por semana. Desse modo, foram inventadas várias pequenas músicas. Ao final, elas fizeram uma apresentação para os pais, professores e diretores do Conservatório. Cada criança escolheu uma obra entre todas as que elas criaram. Evidente- 
mente, escolheram a música que mais gostaram. Em seguida, elas fizeram um pequeno comentário, uma breve análise da própria obra baseada nas discussões realizadas em aula com os demais colegas. Finalmente, escutamos a música e os parentes aplaudiram cada criança. Foi muito bonito ver os pais aplaudindo os próprios filhos. É uma maneira importante de desenvolver a autoestima, o que vai ajudá-los muito na vida.

I9. Então, nesse sentido, gostaríamos que você dissesse qual a importância da educação musical baseada na criação?

Desenvolver a criação, a criatividade, a capacidade de conduzir um projeto, de apresentá-lo aos outros, de ver a reação das pessoas, de ter a aprovação dos próprios pais, enfim, estamos diante de situações que não são banais. É um fator de desenvolvimento importante. O que acho essencial é compreender que há meios educativos, cujo modelo de educação é a obediência, no qual as crianças escutam o tempo todo de maneira imperativa: “- Faça isso, não faça aquilo!” Ora, há meios nos quais as crianças têm a sorte dos adultos não dizerem a elas o tempo todo o que fazer, através dos quais podemos deixá-las, muitas vezes, fazerem por si mesmas, inventar alguma coisa. Nesse momento, elas recebem a aprovação dos parentes: “- É legal isso que você fez!", podendo, eventualmente, mostrar que ela pode fazer ainda melhor, deixá-la ter sua própria iniciativa.

Existe toda uma corrente de pensamento atual que se interessa por essa espécie de fenômeno de classe criativa. Estou falando sobre isso, pois me sinto também ligado ao fenômeno de reprodução social. Isso foi muito falado na Sociologia. Há, notadamente, em Pierre Bourdieu - que escreveu um livro chamado La Reproduction - e todo mundo fala sobre isso, ou seja, as crianças de determinado meio têm dificuldades de sair desse meio. Não é fácil, por exemplo, para os filhos de operários tornarem-se chefes em uma empresa, e sempre se pensou que isto só acontecia porque, para alcançar os estudos superiores, os pais precisavam ter dinheiro. Logo, o dinheiro parecia ser praticamente o único fator determinante.

No entanto, discute-se agora que não é somente isso, mas também o fato de 
ensinarmos as crianças a fazerem tudo o que dizemos. Elas são pré-fabricadas - se assim posso dizer - para serem, de certa maneira, personagens de execução. Alguém que faz aquilo que dizemos para fazer. Entretanto, há pessoas que têm papéis na sociedade que são papéis criativos e, para desempenhar tais papéis, vale mais sermos criados num meio que nos permita tomar iniciativas.

Afinal, conceder iniciativa a uma criança, deixá-la inventar, descobrir, conduzir seus próprios projetos é favorecer justamente uma forma de criação, isto é, estimular a possibilidade de criar, seja no âmbito musical, empresarial, associativo, etc. é acreditar que você pode fazer algo e que isso pode funcionar. É lançar um projeto. Ter confiança nesse projeto, ter confiança em si mesmo o suficiente para conduzir esse projeto até o fim. 